26. Lentino JR, Rosenkranz MA, Michaels JA, Kurup VP, Rose HD, Rytel MW. Nosocomial aspergillosis: a retrospective review of airborne disease secondary to road construction and contaminated air conditioners. Am J Epidemiol 1982;116:430-437.

27. Sarubbi FA, Kopf HB, Wilson MB, McGinnis MR, Rutala WA. Increased recovery of Aspergillus flavus from respiratory specimens during hospital construction. Am Rev Respir Dis 1982;1125:33-38.

28. Weber SF, Peacock JE, Do KA, Cruz JM, Powell BL, Capizzi RL. Interaction of granulocytopenia and construction activity as risk factors for nosocomial invasive filamentous fungal disease in patients with hematologic disorders. Infect Control Hosp Epidemiol 1990;11:235-242.

29. Arnow PM, Sadigh M, Costas C, Weil D, Chudy R. Endemic and epi- demic aspergillosis associated with in-hospital replication of Aspergillus organisms. I Infect Dis 1991;164:998-1002.

30. Loudon KW, Coke AP, Burnie JP, Lucas GS, Liu Yin JA Invasive aspergillosis: clusters and sources? J Med Vet Mycol 1994;32:217-224.

31. Humphreys H, Johnson EM, Warnock DW, Willats SM, Winter RJ, Speller DCE. An outbreak of aspergillosis in general ITU. J Hosp Infect 1991;18:167-177.

32. Richet HM, Mc Neil MM, Davis BJ, Duncan E, Strickler J, Nunley D, et al. Aspergillus fumigatus sternal wound infections in patients undergoing open heart surgery. Am J Epidemiol 1992;135:48-58.

33. Lajonchere JP, Feuilhade de Chauvin M. Contamination aspergillaire: évaluation des mesures de prévention et surveillance de l'environnement. Pathol Biol (Paris) 1994;42:718-729.

\title{
OSHA Plans to Combat Needlestick Injuries
}

\section{Gina Pugliese, RN, MS Martin S. Favero, PhD}

OSHA has announced that it is moving to reduce the number of injuries healthcare workers get from needles and other sharp medical objects, noting that an estimated 590,000 needlestick injuries occur each year. This action was prompted in part by a report summarizing nearly 400 comments from healthcare facilities, workers, and others who responded to the agency's request for information last fall. At that time, OSHA asked for ideas and recommendations on better ways to protect workers from contaminated needles or other sharp objects.

"Safer needle devices mean fewer needlesticks for healthcare workers," Secretary of Labor Alexis M. Herman said. "It is time to make sure that healthcare workers have upto-date medical devices that limit the risk of needlesticks and the potential for developing deadly diseases such as AIDS and hepatitis."
OSHA is pursuing a threepronged approach to help minimize the risk of occupational exposure to bloodborne diseases due to needlestick injuries.

First, the agency already proposed a requirement in the revised Recordkeeping Rule that all injuries resulting from contaminated needles and sharps be recorded on OSHA logs, used by employers to record injuries and illnesses. Final action in the rule making, which will be based on OSHA's evaluation of the public rule-making record, is scheduled for this fall.

Second, OSHA will revise the bloodborne pathogens compliance directive later this year to reflect the newer and safer technologies now available. The directive is used by OSHA's compliance officers to enforce the agency's Bloodborne Pathogens Standard.

Third, the agency will take steps to amend the Bloodborne Pathogens Standard by placing needlestick and sharps injuries on its regulatory agenda this fall.
In its review of the comments received from the information request, OSHA found that a variety of safer devices exist that can protect workers from needlestick and sharp injuries; however, these devices are not being used widely enough to reduce substantially the hundreds of thousands of injuries each year.

Further, the report notes that training and education in the use of safer medical devices and safe work practices have proven effective in preventing exposures. Finally, responses indicate that staff involvement in the selection process plays an important role in the acceptance and proper use of safer medical devices.

The report "Record Summary of the Request for Information on Occupational Exposure to Bloodborne Pathogens Due to Percutaneous Injury" and the text of the news release "Labor Secretary Announces Plans To Combat Needlestick Injuries Among Healthcare Workers" May 20,1999, is available on OSHA's web site at www.osha.gov. 